\title{
The right to be information literate: the core foundation of the knowledge society
}

\section{Johannes Britz and Peter Lor}

Johannes Britz

University of Wisconsin-Milwaukee

and University of Pretoria

britz@uwm.edu

Peter Lor

University of Wisconsin-Milwaukee

and University of Pretoria

lorpj@uwm.edu

\section{Abstract}

This article considers the origins and essence of human rights, the requirement that people should have access to information in order to participate in society and develop their human capacity, and the relationship between information and freedom of choice. Information literacy and the right of access to information are interrelated and interconnected. Human freedom implies not only the ability to choose (formal freedom) but also the choices people are able to make (material freedom). It is argued that information literacy, and specifically the ability to evaluate, and benefit from, information, is essential to both formal and material freedom. It is furthermore seen as part of the positive dimension of the right of access to information, and as such implies that the state has a positive duty to protect and promote the right of its citizens to become information literate.

\section{Introduction}

Information literacy is currently a hot topic in library and information science (LIS). On opening the catalogue of any major publisher in our field, one is likely to find a dozen or more newly published books on this topic. It also has a high profile internationally. In November 2005, on the eve of the second World Summit on the Information Society, the International Federation of Library 
Associations and Institutions (IFLA) co-sponsored a High-Level Colloquium on Information Literacy and Lifelong Learning, held at the Biblioteca Alexandrina, which produced a statement entitled "Beacons of the Information Society: the Alexandria Proclamation on Information Literacy and Lifelong Learning", reproduced as Appendix A (Garner 2006). Especially striking in this document is the second paragraph:

Information Literacy lies at the core of lifelong learning. It empowers people in all walks of life to seek, evaluate, use and create information effectively to achieve their personal, social, occupational and educational goals. It is a basic human right in a digital world and promotes social inclusion of all nations.

Here the empowering role of information literacy is seen as a "basic human right". In the same year the Communication and Information Sector of the United Nations Educational, Scientific and Cultural Organization (UNESCO) made information literacy a focal theme (UNESCO 2005) and, linking information literacy with media literacy, stated that it was concerned with empowerment:

Empowerment of people through information and media literacy is an important prerequisite for fostering equitable access to information and knowledge, and building inclusive knowledge societies.

Information and media literacy enables people to interpret and make informed judgments as users of information and media, as well as to become skillful creators and producers of information and media messages in their own right.

UNESCO followed this up by funding a world-wide series of expert meetings and train-the-trainers workshops on information literacy. In 2008 UNESCO's Information for All Program (IFAP), which had chosen information literacy as one of its three priority areas, published Understanding information literacy: a primer (Horton 2008). In his Foreword to this publication Dr Abdul Waheed Khan, UNESCO's Assistant Director-General for Communication and Information, linked information literacy to UNESCO's advocacy for "... the building of knowledge societies where the power of information and communication helps people access the knowledge they need to improve their daily lives and achieve their full potential" (p.i), while Horton explicitly links information literacy to four "key sector domains":

1.Learning and education

2. Health and human services 
3. Business and economic development

4. Governance and citizenship (Horton 2008:15-31).

Interestingly Horton singles out "access to health information" but not the other sectors, as a human right (p. 22).

In another IFAP publication, UNESCO and information literacy (Ito 2008), information literacy is linked to two statements emanating from the World Summit on the Information Society (WSIS). The Geneva plan of action (WSIS 2003), adopted at the 2003 summit in Geneva, stated that "[e]ach person should have the opportunity to acquire the necessary skills and knowledge in order to understand, participate actively in, and benefit fully from, the Information Society". The Tunis Commitment (WSIS 2005) reaffirmed the Summit's "desire and commitment to build a people-centered, inclusive and development-oriented Information Society, where people everywhere can create, access, utilise and share information and knowledge..." A diagram in this IFAP publication (Figure 1) places the edifice of knowledge societies on the foundation of "human needs and rights" (Ito 2008:6).

Figure 1: UNESCO's concept of knowledge societies (Ito 2008:6)

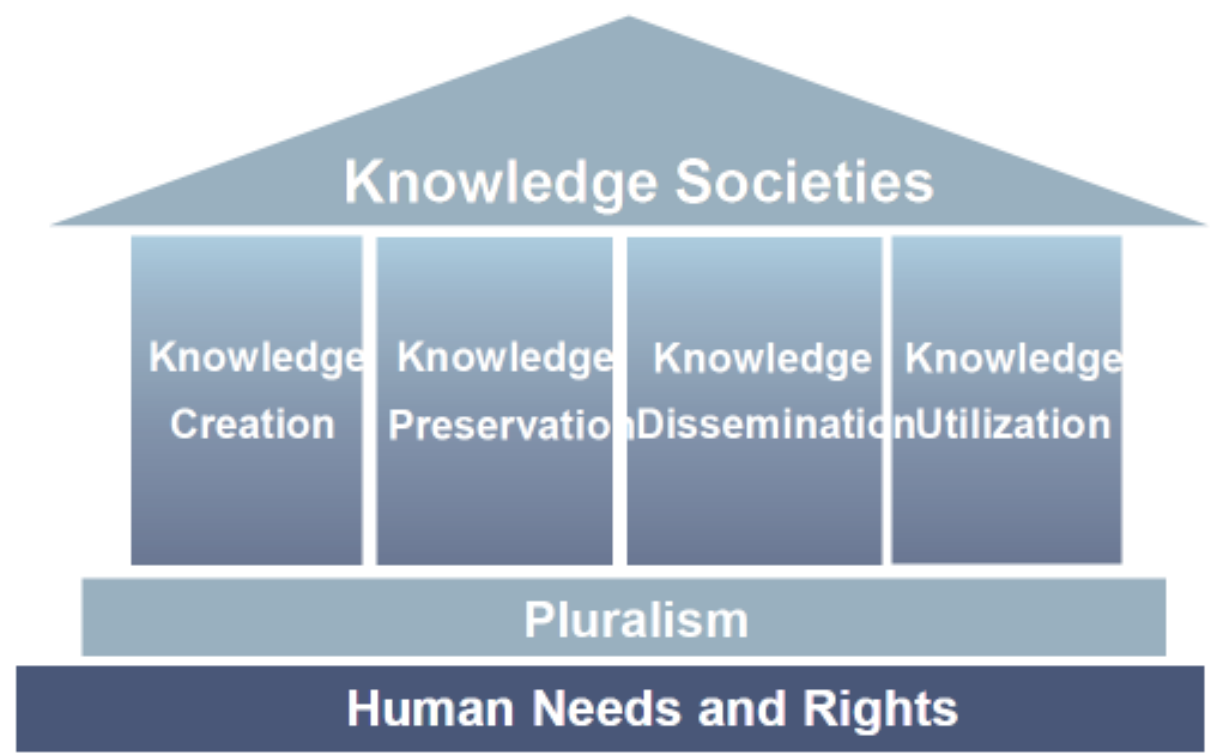

In a second diagram (Figure 2) information literacy is given the corresponding position as the foundation on which knowledge societies should be built. Here information literacy is depicted as enabling access to information and knowledge and as developing the ability to apply and use information and 
knowledge. Upon these two aspects of information literacy are based social participation, learning and cultural expression, as prerequisites for development, prosperity and freedom (Ito 2008:7).

Figure 2: UNESCO's concept of information literacy and knowledge societies (Ito 2008:7)

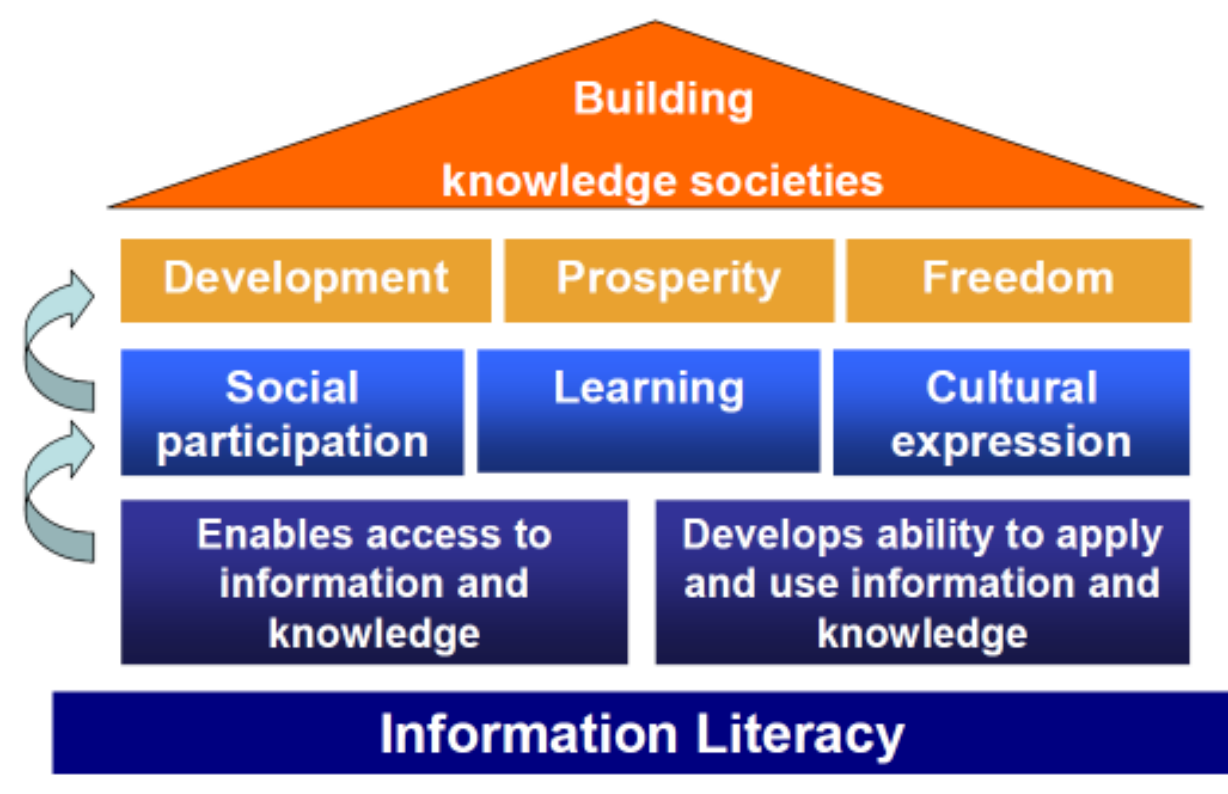

There is a plethora of such statements, often in the overblown rhetoric of international meetings. Similarly the professional literature repeatedly emphasises the fundamental importance of information literacy as a prerequisite for full participation in the modern, digital world. In its report, College learning for the new global century, The Association of American Colleges and Universities (AACU) (2007) also identified information literacy as one of the essential learning outcomes for the twenty first century. The question arises whether this justifies the claim that information literacy should be viewed as a human right. This article examines the place of information literacy within the field of internationally recognised human rights, and brings ethical concepts of human development and social justice to bear on the question of how information literacy relates to information rights: is information literacy a means to an end, or should it be considered a basic instrumental (human) right? 


\section{Information and the Universal Declaration of Human Rights}

The Universal Declaration of Human Rights (United Nations 1948) proclaimed in 1948 by the General Assembly of the United Nations (UN) is internationally the best-known and most widely endorsed statement of human rights. This is not to say that all countries respect all the rights contained therein. It is part of the international diplomatic process that governments cynically endorse declarations they have no intention of honoring and that countries with appalling human rights records get elected to serve on bodies such as the United Nations Human Rights Council, as is obvious if one peruses the list of current members (United Nations Human Rights Council 2010). Nevertheless, as one of the earliest and most fundamental statements of the United Nations, it commands great moral authority, one that is worth defending on global platforms.

In our discussion on human rights we focus primarily on those rights that directly or indirectly deal with information. Article 19 in the Universal Declaration of Human Rights is one these information-related rights:

Everyone has the right to freedom of opinion and expression; this right includes freedom to hold opinions without interference and to seek, receive and impart information and ideas through any media and regardless of frontiers.

Article 19 enshrines the basic principle of freedom of information and is widely seen as a foundational statement on freedom of expression, being cited in par. 4 of the Geneva Declaration of Principles (WSIS 2003). It is also enshrined in the Statutes of IFLA (2010) as the first of IFLA's core values, and is cited in the American Library Association's (ALA) Resolution on IFLA, human rights and freedom of expression (ALA 1997), to name just two examples of influential professional statements. In this literature it is also sometimes referred to as "intellectual freedom", as in the IFLA statement on libraries and intellectual freedom (IFLA 1999). However, the term "intellectual freedom" has connotations of scholarship and academic environments, which tends to limit the concept. The opinions held and expressed should not be seen as being limited to intellectual matters. "Opinions" can also be held on matters of practices, policies and politics, whether at the group, community, local or national levels. It might be better to refer to information-related rights. These rights can be seen as both active (seeking and imparting information) and passive (holding and receiving information), and they pertain to two spheres, 
private (rights pertaining to the individual within his/her own mind) and public (rights of the individual interacting with others). This is diagrammed in Table 1:

Table 1: Dimensions of article 19

\begin{tabular}{|l|l|l|l|}
\hline \multicolumn{2}{|c|}{} & Sphere \\
\cline { 3 - 4 } \multicolumn{2}{|c|}{} & Private & Public \\
\hline \multirow{3}{*}{ Mode } & Passive & Hold & Receive \\
\cline { 2 - 4 } & Active & Seek & Impart/Express \\
\hline
\end{tabular}

A number of other articles in the declaration also have implications for information rights.

Article 12 refers to privacy:

No one shall be subjected to arbitrary interference with his privacy, family, home or correspondence, nor to attacks upon his honor and reputation. Everyone has the right to the protection of the law against such interference or attacks.

Privacy, honor and reputation are all concerned with dissemination of information. In this case, certain restrictions on dissemination are implied. This is primarily a passive right (a right to be left alone).

Article 18 is concerned with freedom of thought, conscience and religion:

Everyone has the right to freedom of thought, conscience and religion; this right includes freedom to change his religion or belief, and freedom, either alone or in community with others and in public or private, to manifest his religion or belief in teaching, practice, worship and observance.

This is both a passive right ("freedom of thought, conscience and religion") and an active right ("to manifest religion or belief"). The four activities include "teaching", which implies the imparting of information.

Article 26 states a right to education:

(1) Everyone has the right to education. Education shall be free, at least in the elementary and fundamental stages. Elementary education shall be compulsory. Technical and professional education shall be made generally available and higher education shall be equally 
accessible to all on the basis of merit.

(2) Education shall be directed to the full development of the human personality and to the strengthening of respect for human rights and fundamental freedoms. It shall promote understanding, tolerance and friendship among all nations, racial or religious groups, and shall further the activities of the United Nations for the maintenance of peace.

(3) Parents have a prior right to choose the kind of education that shall be given to their children.

Again, education implies the imparting of information. In addition, paragraph (2) above implies a very comprehensive and liberal flow of information. Education, as seen here, is not limited to reading, writing and arithmetic, or patriotic history and geography. It has both passive (receiving) and active (imparting) dimensions.

Article 27 is in two parts:

(1) Everyone has the right freely to participate in the cultural life of the community, to enjoy the arts and to share in scientific advancement and its benefits.

(2) Everyone has the right to the protection of the moral and material interests resulting from any scientific, literary or artistic production of which he is the author.

Paragraph (1) states an active right, a right to participation, which implies a right to access information. Paragraph (2) states a passive right, a right to be protected from the exploitation of one's intellectual products, which implies certain limitations on access to information.

There are other articles which have implications for information-related rights. For example, Article 17 states a right to property (individually and in association with others). Read with Article 27(2) this provides a human rights basis for protection of "intellectual property". Article 21(1) states a right to participate in the governance of one's country. This is only effectively possible if every citizen has access to relevant information. Article 21(2) states that everyone has "the right of equal access to public service in his country", which implies an even stronger requirement for information. We suggest that an analysis of the other articles of the Universal Declaration of Human Rights would show that the effective exercise of each of these rights requires dissemination of, and access to, information to everyone. This implies that the information rights stated in Article 19 are in some sense more basic than some other rights, which leads us to the examination of the role that information 
literacy plays in the enablement of these rights. Due to the fact that information literacy is interdependent and interrelated with access to information we focus our discussion in particular on this relationship.

\section{Information literacy: the enabler of the right of access to information}

\section{The essence of human rights}

The phrase 'human rights', as used today, is relatively new and gained popularity after World War II when the then newly formed United Nations adopted the Universal Declaration on Human Rights in 1948. The philosophical notion of human rights has, however, been a subject for deliberations over many centuries starting with the Greeks and Romans. It was introduced in the West during the seventeenth century by John Locke and further conceptualised in the eighteen century by the German philosopher Immanuel Kant (De Villiers 1984).

Human rights are based on the fundamental belief that all humans are of equal value and have basic rights and fundamental freedoms. As such human rights are viewed as the embodiment of those basic rights and fundamental freedoms to which all humans are entitled and which must be validated and protected by society. Ideologically and idealistically human rights are seen as universal and indivisible (Samassekou 2006). According to Hamelink (2000: 59), “...human rights provide currently the only universally available set of standards for the dignity and integrity of all human beings". Although formally recognised by the UN and reaffirmed in 1993 at the Vienna World Conference on Human Rights, the interpretation and application of human rights are neither universal nor uniform. There are different perspectives and different realities resulting in different articulations and legal interpretations of human rights. In some cultures the very notion that humans should have basic human rights is rejected (De Villiers 1984).

Human rights furthermore reflect the following moral principles (Hamelink 2000: 62):

- Equal value of all people, implying that discrimination is inadmissible.

- Security and safety, implying that harm against human integrity is inadmissible;

- Freedom, implying that interference with human development and selfdetermination is inadmissible. 
As such human rights are closely associated with justice because, as a moral principle, it demands the recognition of human freedom and equal value of all as well as the rightful protection of basic rights of each and every person. Human rights are therefore the legal articulation of the fundamental principles of justice (Rawls 1971).

Traditionally human rights are divided into civil, political, cultural, social and economic rights. Three generations of rights are distinguished by Kaufman (2005). The civil and political rights, dealing with the freedom to participate in political activities as well as liberty, are referred to as the first generation of human rights. The right to freedom of expression, which we identified as one of the core information-related rights, is seen as a first generation right. The second generation of human rights deals with human equality and is expressed in the social, economic and cultural rights and includes the right to education. The so-called third generation human rights go beyond the civil and social rights in articulating rights pertaining to the environment, sustainability as well as groups (collective rights of people). Kaufman includes in this category the right to communication. Although the third generation of human rights does not enjoy the same level of international recognition, it has been successfully codified in the legislation of a numbers of countries including South Africa (1996).

It was only as recently as 2003, at the first World Summit on the Information Society (WSIS), and the follow-up summit in 2005, that the international community formally recognized that the development and sustainability of a global information and knowledge society should be based on the premises of universally accepted human rights, in particular, information-related rights such as the right of access to information, the right to privacy, the right to intellectual property and the right to communicate. Information-related human rights have therefore gained currency in the human rights discourse over the last decade. It has been recognised that information and communication have become the 'nerve centre' of information and knowledge societies. Samassekou articulates it as follows: "As societies transform into information societies, the ability to communicate and learn becomes the important societal skill" (2006: viii).

\section{Access to information: an instrumental basic human right}

The notion of human beings having the freedom, as articulated in human rights, to exercise civil and political rights, freedom of economic participation and the ability to enjoy their individual liberties and socio-cultural rights can therefore only be actualised if there is access to the information needed to exercise these 
rights. Access to information is not only essential for self determination, but also instrumental to all human activities. The right to education would be ineffective if pupils did not have access to information and the right to political participation would be of little use if governments were not transparent. Information, and access thereto, can indeed be equated to fresh air. Without it we can neither survive nor thrive. Thus we argue that information has instrumental value because it allows us to make choices, raise our voices, participate in different socio-economic, political and cultural activities and improve our capacity as humans. Access to information should therefore be regarded as an instrumental and basic human right because any vision of the successful implementation and protection of our civil, political, cultural, economic and social rights without the right of access to information pertaining to these rights, would be futile. This explains why the Council of Europe (2007) recognises that lack of access or limited access to information can deprive individuals of the ability to exercise their other basic human rights. The South African Constitution (South Africa 1996) rightfully defines the right of access to information within this framework. Chapter 2, section 32 states that "Everyone has the right of access to any information held by the state; and any information that is held by another person and that is required for the exercise or protection of any rights." (South Africa 1996). In the same vein the WSIS (2005) has accepted a similar declaration, namely that the ability to access information and the communication thereof is fundamental to participation in all social processes and it is instrumental in satisfying most of our other human rights.

The argument that access to information is an instrumental basic human right not only implies the protection of this right, for example, in a constitution and by means of legislation, but also ensuring the enabling of this right. By enabling a right we mean that society should put in place those measures that will ensure that people are able to understand and interpret the information they access. We agree that, when talking about the prioritisation of human rights, one needs to be careful and even cautious, since contexts can differ. However, based on the instrumental value of information, we do argue that the right of access to information should have a high priority. Pressure should be put on governments to put this right high on their constitutional agendas because they have a moral obligation and legal responsibility to create an accessible information infrastructure together with a legal regime that will allow citizens not only the protection of this right, but also the means and ways for exercising it. 


\section{Information literacy: enabler of the right of access to information and instrumental to human freedom}

Acknowledging and protecting the right of access to information is, however, not enough. People need to be empowered to seek, evaluate, use and benefit from, the information pertaining to their human rights. It is one thing for a government to make information available about where and how to apply for an identity card. But citizens need to know where and how to search for this information, be able to evaluate it and understand how to fill out the required form. Thus information literacy skills are a precondition for the implementation and successful exercise of the right of access to information. Access to information alone does not guarantee the accessibility and proper use thereof. We therefore argue that information literacy should be regarded as the positive dimension of the right of access to information: this right is interrelated with information literacy.

Information literacy is furthermore instrumental to our human freedom because an information literate person is empowered to make informed decisions. As such there is a very distinct relationship between human freedom and information literacy. This relationship can be explained in the following manner: Human freedom not only relates to our ability to choose, but also to the content of the choices that we make. The ability to choose is known as formal freedom and the choices we make are referred to as material freedom (De Villiers 1984). Information literacy has a direct bearing on both these categories of choices. Without the knowledge on how to appropriately access and retrieve needed information for example, from a library catalogue or via search engines on the Internet, our ability to choose (formal freedom) will be seriously limited and/or hampered. Our material freedom (what we choose) is also closely related to information literacy - in particular the ability to evaluate, and benefit from, the retrieved information. The inability to filter out irrelevant, biased and incorrect information affects our ability to make informed choices (Britz 1996: 244).

In the era of globalisation and the digital economy, one can furthermore argue that limited information literacy skills have a negative impact on two abilities. On the one hand, such a limitation affects the ability to access relevant and accurate information. On the other, the inability to make meaningful use of the retrieved information not only limits our choices, but also limits our ability to participate in the different information-based socio-economic and political activities - in other words: our freedom to participate. Indeed, information 
literacy is a precondition for freedom, since it comprises the ability to access information as well as to put relevant and accurate information to use.

The fact that information literacy is part of the positive dimension of the right of access to information implies that there is a positive duty on the state to ensure that its citizens have equal opportunities to become information literate. Thus the state has a moral and legal responsibility to ensure the protection and enhancement of information literacy. As a positive enabler of the right of access to information, information literacy needs political and legal recognition. Guided by the moral principle of social justice, society should ask for example, whether people are information literate and whether resources such as libraries, information literacy programmes and schools are available that will ensure that people will be able to acquire this literacy skill. Are these resources present, accessible, affordable and ideological neutral? In other words, are society and policies structured in such a manner that they accommodate and support actions and activities to achieve information literacy?

\section{Conclusion}

Information literacy has indeed become a hot topic, not only in LIS education, but also in wider higher education forums, in particular as it relates to the 'General Education Requirements' (GER) discussion which is taking place at university and college levels around the world (Association of American Colleges and Universities 2007). Leading international organisations such as IFLA and UNESCO are putting forward a strong case for information literacy to be recognised as a universal human right because of the empowering role that it plays in the lives of individuals.

In this paper we examined this claim of information literacy within the field of internationally recognised human rights. We concluded that information literacy:

- Is instrumental to the enabling of the right of access to information and as such should be recognised as part of the positive dimension of this right and that the state has a positive duty to ensure the active enablement thereof

- Is closely tied to another fundamental right namely our freedom. We argued that information literacy is not only instrumental to our formal freedom (the ability to choose) but also our material freedom (the choices we make) 


\section{Acknowledgement}

The authors thank an anonymous reviewer for providing additional insight on the relationship between information literacy and the right of access to information.

\section{References}

American Library Association. 1997. Resolution on IFLA, human rights, and freedom of expression.

http://www.ala.org/ala/aboutala/offices/iro/awardsactivities/resolutionifla.cfm Accessed 15 October 2010.

Association of American Colleges and Universities. 2007. College learning for the new global century. A report from the National Leadership Council for Liberal Education and America's Promise. Washington D C: AACU. http://www.aacu.org/leap/documents/GlobalCentury_final.pdf Accessed 23 August 2010.

Britz, J.J. 1996. Inligtingsetiek - met spesifieke verwysing na die beroep van die inligtingkundige: 'n Christelike perspektief. D.D. Proefskrif. Pretoria: Universiteit van Pretoria.

Council of Europe .2007. Recommendation/CM/Rec(2007)11 of the Committee of Ministers to member states on promoting freedom of expression and information in the new information and communications environment. https://wcd.coe.int/wcd/ViewDoc.jsp?id=1188541 Accessed 8 February 2011.

De Villiers, D.E. 1984. Die geskiedenis van menseregte. In Du Toit, D.A. (red.) Menseregte: opstelle onder redaksie van D.A. du Toit. Kaapstad: Tafelberg. pp. 9-38.

Garner, Sarah Devotion. 2006. High-Level Colloquium on Information Literacy and Lifelong Learning, Bibliotheca Alexandrina, Alexandria, Egypt November 6-9, 2005. Report of a meeting sponsored by the United Nations Education, Scientific, and Cultural Organisation (UNESCO), National Forum on Information Literacy (NFIL) and the International Federation of Library Associations and Institutions (IFLA). http://archive.ifla.org/III/wsis/High-LevelColloquium.pdf Accessed 5 May 2010. 
Hamelink, C.J. 2000. Ethics in cyberspace. London: SAGE Publications.

Horton, Forest Woody. 2008. Understanding information literacy: a primer. Paris: UNESCO (CI-2007/WS/18 - CLD 3008.7) http://unesdoc.unesco.org/images/0015/001570/157020E.pdf Accessed 23 August 2010.

International Federation of Library Associations and Institutions. 1999. IFLA statement on libraries and intellectual freedom. http://archive.ifla.org/faife/policy/iflastat/iflastat.htm. Accessed 13 October 2010 .

International Federation of Library Associations and Institutions. 2006. Beacons of the Information Society: The Alexandria Proclamation on Information Literacy and Lifelong Learning. http://archive.ifla.org/III/wsis/BeaconInfSoc.html Accessed 20 August 2010..

International Federation of Library Associations and Institutions. 2010. IFLA statutes. http://www.ifla.org/files/hq/ifla-statutes-en.pdf Accessed 13 October 2010 .

Ito, Misako. 2008. UNESCO and information literacy. Paris: UNESCO. http://www.humanit.org/PID/Unesco_april08/Ito_InformationLiteracy.pdf Accessed 4 May 2010.

Kaufmann, D. 2005. Human rights and governance: the empirical challenge. In Alston, Philip and Robinson, Mary (eds.) Human rights and development: towards mutual reinforcement. Oxford: Oxford University Press. pp. 352-402.

Rawls, J. 1971. A theory of justice. Oxford: Oxford University Press.

Samassekou, A. 2006. Foreword. In Jorgensen, Rikke Frank (ed.) Human rights and the global information society. London: MIT Press. pp. vii-x.

South Africa. 1996. Constitution of the Republic of South Africa, 1996. http://www.info.gov.za/documents/constitution/1996/index.htm Accessed 20 August 2010.

United Nations. 2010. Human Rights Council. Membership. http://www2.ohchr.org/english/bodies/hrcouncil/membership.htm Accessed 3 February 2011. 
United Nations. General Assembly. 1948. Universal Declaration of Human Rights. http://www.un.org/en/documents/udhr/ Accessed 30 January 2011.

United Nations Educational, Scientific and Cultural Organization. 2005. UNESCO and information literacy. http://portal.unesco.org/ci/en/ev.php-

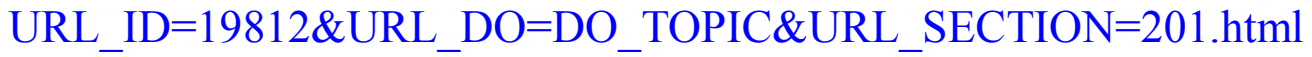
Accessed 4 April 2010.

WSIS see World Summit on the Information Society

World Summit on the Information Society. 2003. The Geneva declaration of principles and plan of action. Geneva: WSIS Executive Secretariat. http://www.itu.int/wsis/docs/geneva/official/dop.html Accessed 20 August 2010.

World Summit on the Information Society. 2005. Tunis agenda for the information society. WSIS-05/TUNIS/DOC/6 (rev. 1).

http://www.itu.int/wsis/docs2/tunis/off/6rev1.html Accessed 20 August 2010. 
APPENDIX A:

\section{BEACONS OF THE INFORMATION SOCIETY THE ALEXANDRIA PROCLAMATION ON INFORMATION LITERACY AND LIFELONG LEARNING}

Celebrating this week's confirmation of the site of the Pharos of Alexandria, one of the ancient wonders of the world, the participants in the High-Level Colloquium on Information Literacy and Lifelong Learning held at the Bibliotheca Alexandrina on 6-9 November 2005 proclaim that Information Literacy and lifelong learning are the beacons of the Information Society, illuminating the courses to development, prosperity and freedom.

Information Literacy lies at the core of lifelong learning. It empowers people in all walks of life to seek, evaluate, use and create information effectively to achieve their personal, social, occupational and educational goals. It is a basic human right in a digital world and promotes social inclusion of all nations.

Lifelong learning enables individuals, communities and nations to attain their goals and to take advantage of emerging opportunities in the evolving global environment for shared benefit. It assists them and their institutions to meet technological, economic and social challenges, to redress disadvantage and to advance the well being of all.

Information Literacy

- comprises the competencies to recognise information needs and to locate, evaluate, apply and create information within cultural and social contexts;

- is crucial to the competitive advantage of individuals, enterprises (especially small and medium enterprises), regions and nations;

- provides the key to effective access, use and creation of content to support economic development, education, health and human services, and all other aspects of contemporary societies, and thereby provides the vital foundation for fulfilling the goals of the Millennium Declaration and the World Summit on the Information Society; and

- extends beyond current technologies to encompass learning, critical thinking and interpretative skills across professional boundaries and empowers individuals and communities.

Within the context of the developing Information Society, we urge governments and intergovernmental organisations to pursue policies and programmes to promote Information Literacy and lifelong learning. In 
particular, we ask them to support

- regional and thematic meetings which will facilitate the adoption of Information Literacy and lifelong learning strategies within specific regions and socioeconomic sectors;

- professional development of personnel in education, library, information, archive, and health and human services in the principles and practices of Information Literacy and lifelong learning;

- inclusion of Information Literacy into initial and continuing education for key economic sectors and government policy making and administration, and into the practice of advisors to the business, industry and agriculture sectors;

- programmes to increase the employability and entrepreneurial capabilities of women and the disadvantaged, including immigrants, the underemployed and the unemployed; and

- recognition of lifelong learning and Information Literacy as key elements for the development of generic capabilities which must be required for the accreditation of all education and training programmes.

We affirm that vigorous investment in Information Literacy and lifelong learning strategies creates public value and is essential to the development of the Information Society.

Adopted in Alexandria, Egypt at the Bibliotheca Alexandrina on 9 November 2005 